\title{
THE IDENTIFICATION OF A MARQUESAN ADZE IN THE COOK ISLANDS
}

\section{ANDREW MCALISTER, PETER J. SHEPPARD and MELINDA S. ALLEN University of Auckland}

The islands of East Polynesia were among the last places on Earth to be settled by humans. To embark on such an undertaking, involving hundreds of islands separated by thousands of kilometres of ocean, would almost certainly have required a high degree of organisation, and many of the questions that have interested archaeologists working in the region revolve around how this feat was achieved (see Allen and Kahn 2010, Kirch and Kahn 2007 for reviews of recent research). Irwin $(1990,1992)$ has shown that a deliberate and coordinated strategy of exploration provides the most plausible explanation for the discovery of habitable islands, while other researchers have argued that some degree of post-colonisation interaction would have been needed to maintain viable settlements on ecologically-marginal islands (e.g., Di Piazza and Pearthree 2001; Weisler 1993, 1997a).

Archaeologists have employed various lines of evidence to demonstrate this kind of mobility and interaction between communities. Some types of evidence, such as stylistic similarities of artefacts and architecture, shared genetics, common languages and the remains of introduced plants and animals, can demonstrate initial contacts (or common origins) but they will not necessarily reflect on-going relationships. A less ambiguous and more direct method of demonstrating interaction has been to identify the presence of exotic objects made from compositionally distinctive materials. In other parts of the world, such materials have included obsidian (e.g., Cann and Renfrew 1964, Hughes 1986), various metals (Hosler and Macfarlane 1996, Knapp 2000), manufactured glasses (Saitowitz and Read 2001), ceramics (Kennett, Anderson, Cruz et al. 2004) and shell valuables (Aswani and Sheppard 2003, Kirch 1988: 108). However, with the exception of obsidian and volcanic glass, which is common only in New Zealand, Rapa Nui and Hawai'i (McCoy, Mills, Lundblad et al. 2011; Sheppard, Irwin, Lin et al. 2011; Ward 1972), these materials are absent or extremely rare in precontact East Polynesian assemblages (Weisler 1993: 19). For this reason, archaeologists working in Polynesia have for the most part concentrated on identifying the geographical origins of adzes and other tools made from basalt, a commonly-occurring volcanic stone, using X-ray fluorescence spectrometry (XRF) and related techniques (Parker and Sheppard 1997, Shackley 2010, Weisler and Sinton 1997). 


\section{GEOCHEMICAL BASALT ANALYSES IN POLYNESIA}

Over the past three decades, geochemical analyses of basalt tools have been increasingly employed as the primary means of identifying interaction in Polynesia. Early provenancing studies were, however, somewhat limited by relatively small sets of reference data. For example, Best's (1984) pioneering study of Pacific adze geochemistry included only 35 reference specimens from across the region and some sources were represented by single samples. Since then, concerted efforts have been made to systematically sample and analyse most of the major Polynesian basalt sources (e.g., Allen and McAlister 2013; Best, Sheppard, Green et al. 1992; Bollt 2008; Hermann 2011; Johnson 2005, 2010; Kahn, Mills, Lundblad et al. 2008; Kahn, Sinton, Mills et al. 2013; McAlister 2011; Mills, Lundblad, Smith et al. 2008, Mills, Lundblad, Field et al. 2010; Mills, Lundblad, Hon et al. 2011; Mintmier, Mills and Lundblad 2012; Sheppard, Sand and Parker 2001; Sheppard, Walter and Parker 1997; Walter and Sheppard 2001; Weisler 1993, 1998; Weisler, Conte and Kirch 2004; Weisler, Kirch and Endicott 1994; Weisler, Collins, Feng et al. 2013; Winterhoff 2007), resulting in geochemical data for more than 2000 reference specimens. Consequently, analysts are now in a better position to understand the characteristics of various sources, including the ranges of their internal variability.

Provenancing studies have shown that most communities in Polynesia did not develop in isolation but remained in contact with one another for several centuries after colonisation. Weisler (1997b, 1998, 2008), who has been at the forefront of this research, has identified a number of distribution patterns, which he suggests reflect interaction spheres of varying scales. Two basalt sources in particular have very wide distributions (Fig. 1). Adzes from the Tataga Matau Quarry on the Samoan island of Tutuila have been identified in several West Polynesian assemblages, including the Polynesian outlier of Taumako in the Solomon Islands (Best et al. 1992), and were distributed eastwards to the Cook Islands (Allen and Johnson 1997, Sheppard et al. 1997, Weisler 1993). Similarly, tools sourced to Eiao, an extensive "island-quarry" of fine-grained basalt in the north of the Marquesas archipelago (Charleux, McAlister, Mills et al. in press; Linton 1925; Rolett 2001), have been found in several central East Polynesia assemblages (Collerson and Weisler 2007, Hermann 2011, Weisler 1998) and even as far north as the Line Islands (Di Piazza and Pearthree 2001).

A notable feature of large-scale distributions is that they tend to involve the transfer of materials from large, high-quality sources to islands either possessing basalts of lower quality or altogether lacking adze-quality stone. Within island groups possessing extensive sources of high-quality basalt, distributions often are limited to intra-archipelago sources. For example, four 


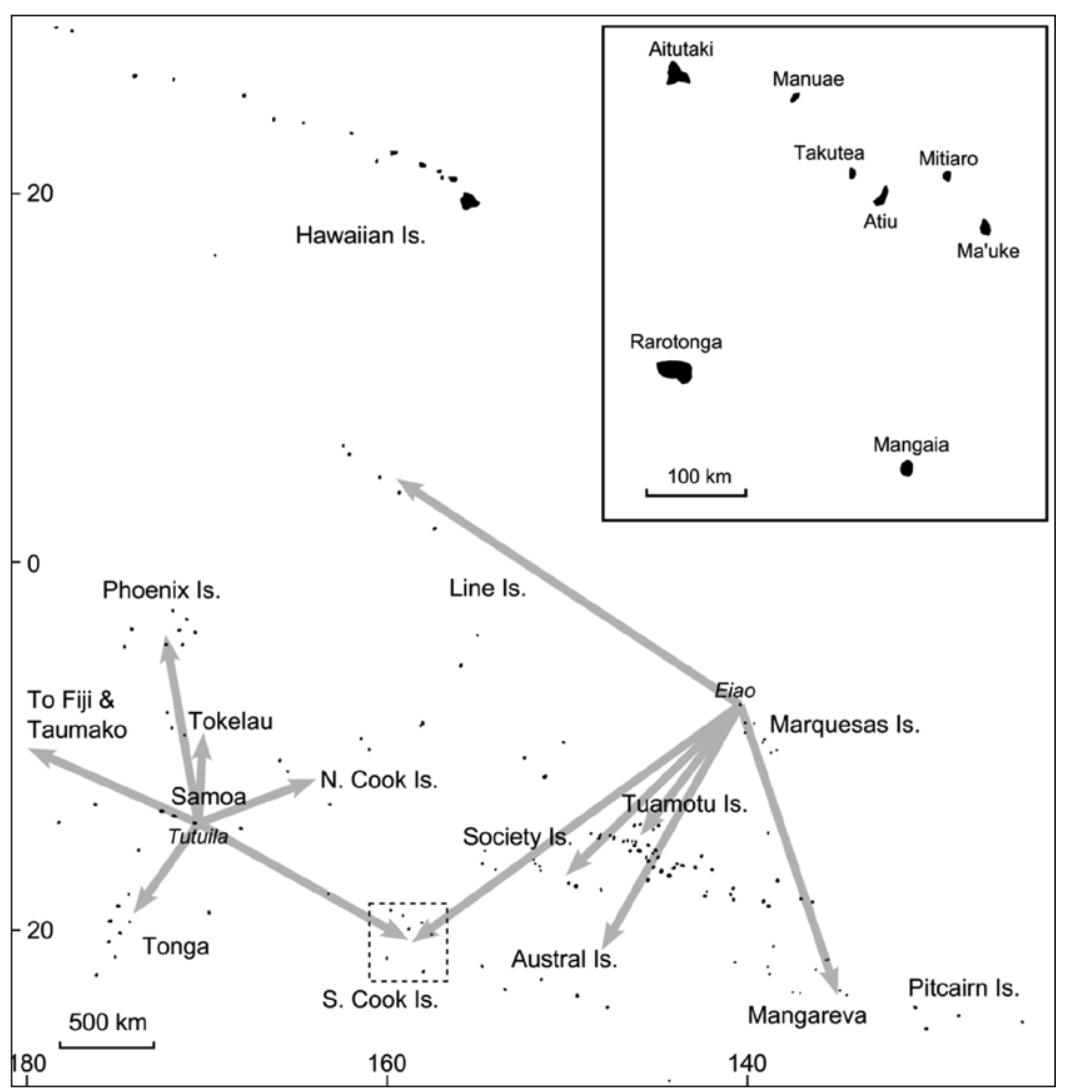

Figure 1.Central Polynesia, showing known distributions of basalt from Tutuila, Samoa (left) and Eiao, Marquesas Islands (right). Inset: the southern Cook Islands.

studies have geochemically analysed basalt tools from Marquesan sites (Allen and McAlister 2013; McAlister 2011; Rolett 1998; Rolett, Conte, Pearthree et al. 1997) and all have found that the assemblages contained only Marquesan stone. Additionally, basalt from Eiao was identified in all of the assemblages that were examined. Similarly, several studies of assemblages in the Hawaiian Islands, where high-quality fine-grained stone is widespread, have found that basalts from within the archipelago were widely distributed but, thus far, no examples of imported stone have been identified (see for example Kahn et al. 2008, 2013; Kirch, Mills, Lundblad et al. 2012; Mills et al. 2010). 
In contrast, island groups without large reserves of fine-grained toolquality basalt tend to have high proportions of imported stone from several sources. To date, Collerson and Weisler's (2007) analysis of adzes collected in the Tuamotu Islands, a group of mainly coral atolls completely lacking in basalt sources, has identified the greatest diversity of imported tools. From a relatively small sample of 19 specimens, they found adzes imported from several East Polynesian sources. These included examples from sources in the Society Islands, Rapa and Rurutu in the Australs, Pitcairn, Eiao in the Marquesas, and even one example from the Hawaiian island of Kaho'olawe over $4000 \mathrm{~km}$ to the north.

\section{PROVENANCING STUDIES IN THE COOK ISLANDS}

The Cook Islands, the focus of this communication, fall between the extremes represented by the Tuamotu and Marquesas Archipelagos. While there are several local sources of fine-grained basalt that were regularly worked into adzes and distributed within the group (see Allen and Johnson 1997; Sheppard et al. 1997: 87; Walter 1990, 1998; Weisler et al. 1994), no extensive quarries of high-quality basalt have been identified in the Cook Islands. Sheppard and Walter (Sheppard et al. 1997, Walter and Sheppard 2001) systematically surveyed the islands with aim of locating and sampling potential basalt sources for geochemical analysis and concluded that local basalt was primarily exploited from river cobbles and small localised dike exposures. Additionally, they suggested that the comparatively low silica content, and propensity to weathering typical of Cook Island basalts, might result in poor flaking properties. It is perhaps for these reasons that Cook Island provenancing studies have identified materials imported from other island groups. Stone from Samoa has been found on most of the southern Cook Islands, including Mangaia (Sheppard et al. 1997, Weisler 1993), Rarotonga (Sheppard et al. 1997, Walter and Sheppard 1996), Ma'uke (Best et al. 1992; Walter 1990, 1998), Aitutaki (Allen and Johnson 1997), and possibly also on Pukapuka in the northern Cook Islands (Best et al. 1992: 81). Several of these studies also have identified a smaller number of adzes from the Society Islands that were tentatively sourced to Ra'iatea Island (Allen and Johnson 1997, Sheppard et al. 1997, Walter 1990, Walter and Sheppard 1996).

In addition to collecting reference specimens, Sheppard et al. (1997: 86; see also Walter and Sheppard 1996) sampled 40 adzes from the Cook Islands Library and Museum Society collections. In their analysis, the majority of these were found to be compatible with intra-archipelago sources on Rarotonga, Ma'uke, and Aitutaki. They also identified imports from Samoa and the Society Islands, and noted that a few adzes possessed chemical compositions that could not be readily associated with known sources. One specimen that was 
considered both physically and geochemically distinct was an adze (identified as R68-1) with a reversed-triangular section (i.e., Duff Type 3A) that, according to the Museum's records, was collected on Rarotonga (Sheppard et al. 1997: Appendix 6a). The authors suggested that the adze was probably exotic on the grounds that it possessed a particularly low niobium concentration and plotted away from the other specimens in their sample (Sheppard et al. 1997: 101). Additionally, a thin-section taken from this adze showed that the specimen was atypical of Cook Island adze-stone in that it contained biotite, the groundmass was extremely fine-grained and phenocrysts were very rare.

In the following section, we report on a re-analysis of this adze, drawing on reference data from recent studies, and suggest that Eiao Island in the Marquesas is its most likely origin. When Sheppard, Walter and Parker conducted their analysis, not much was known about the geochemical properties of Marquesan tool-stone in general, or that of Eiao in particular. Best (1984: 403; see also Best et al. 1992) had analysed four Marquesan basalt samples from the Bernice P. Bishop Museum collections, including a flake from Eiao (AN42), for major oxides only. Since then, a number of studies have provided a more comprehensive understanding of the characteristics and variability of Eiao tool-stone. In 1997, Sinton and Sinoto published a quarry average for Eiao based on major element analyses of 19 adzes collected on various Marquesan islands and attributed to Eiao on the grounds of geochemical similarities (John Sinton pers. comm., 23 January 2008). In addition, trace element concentrations were determined for three of the specimens. It was not until 1998, however, the year after Sheppard, Walter and Parker's study, that the first securelyprovenanced geochemical source data for Eiao were published. Weisler (1998: 523) selected three flakes from an assemblage of "shop fragments" collected on Eiao by Robert Suggs (1961) in the late 1950s and analysed them for both major and trace elements using Wavelength Dispersive X-ray Fluorescence (WDXRF). Collerson and Weisler (2007) subsequently re-analysed one of these flakes (832-1) for an extended range of elements and isotopes. More recently, McAlister (2011) analysed a large sample of adzes from the Marquesas and reported WDXRF data for one additional sample collected on Eiao and for 24 adzes collected on Nuku Hiva and attributed to Eiao. Overall, these studies have found that both source samples from Eiao, and artefacts assigned to the island, cluster closely together on plots and are geochemically distinct from all other known Polynesian adze-stone sources. Physical analyses of thin-sectioned specimens of Eiao basalt also have noted that the material has a distinctive dark grey colour, an extremely fine-grained matrix and few phenocrysts (Charleux et al. in press, McAlister 2011, Rolett et al. 1997). 


\section{RE-ANALYSIS OF THE R68-1 ADZE}

While successive studies of many Pacific basalt sources are resulting in increasingly detailed insights into the production and distribution of stone tools in the region (Kahn et al. 2013, Kirch et al. 2012, Winterhoff 2007), the large geochemical datasets generated by such studies have, at the same time, complicated provenancing methods. The earliest investigations found that bivariate scatterplots or ternary diagrams allowed good discrimination among the relatively small sets of reference data available at the time (see for example Best 1984, Best et al. 1992, Weisler 1993). However, as reference databases are updated to include current information, a number of sources are becoming more difficult to separate by such simple means. As Figure 2 illustrates, bivariate plots of the trace element ratios niobium/strontium against zirconium/strontium, which served well in earlier studies (Allen and Johnson 1997, Sheppard et al. 1997, Weisler 1993), now show considerable overlap among many island groups.

One response to this situation has been to employ multivariate techniques, such as Principle Components and Discriminant Function Analyses (following Johnson 2005, McAlister 2011). While these sorts of techniques are useful for complex datasets, they tend to be methodologically involved, and the results often are difficult to present in a clear and concise format (e.g., Neff 1995). Another method of analysing large datasets that has been successful in geochemical provenancing studies is to use a recursive or nested approach, in which a complex problem is divided into a series of simpler steps by successively excluding the most dissimilar sources (see Baxter 1994, Hancock, Hancock and Hancock 2008, McAlister 2011, Weisler 1993: 143). Restricting the axes of the scatterplot shown in Figure 2 shows that reference samples from only three archipelagos - Hawai' ${ }^{i}$, the Marquesas and Samoacluster near the R68-1 adze (Fig. 3). Additionally, these samples derive from single sources within each of those archipelagos: the Hawaiian samples are all from Kīlauea Caldera on Hawai' $i$ Island, the Marquesan samples are all from Eiao, while the single Samoan specimen, which is compositionally similar to the R68-1 adze, is from Malaeloa, Tutuila (Winterhoff 2007: Appendix C, Sample E). Despite the overlap in their element ratios, the three sources are easily separated when trace element concentrations are examined, and the adze repeatedly clusters closest to the Eiao specimens, suggesting that this is the most probable source (Fig. 4).

As Weisler and Sinton (1997: 180) suggested, the most secure way to match an unknown sample to a source is to examine the concentrations of all measured elements (Table 1). To quantify the similarity of artefacts to sources, Collerson and Weisler (2007) have employed a ratio measure (A/S), 


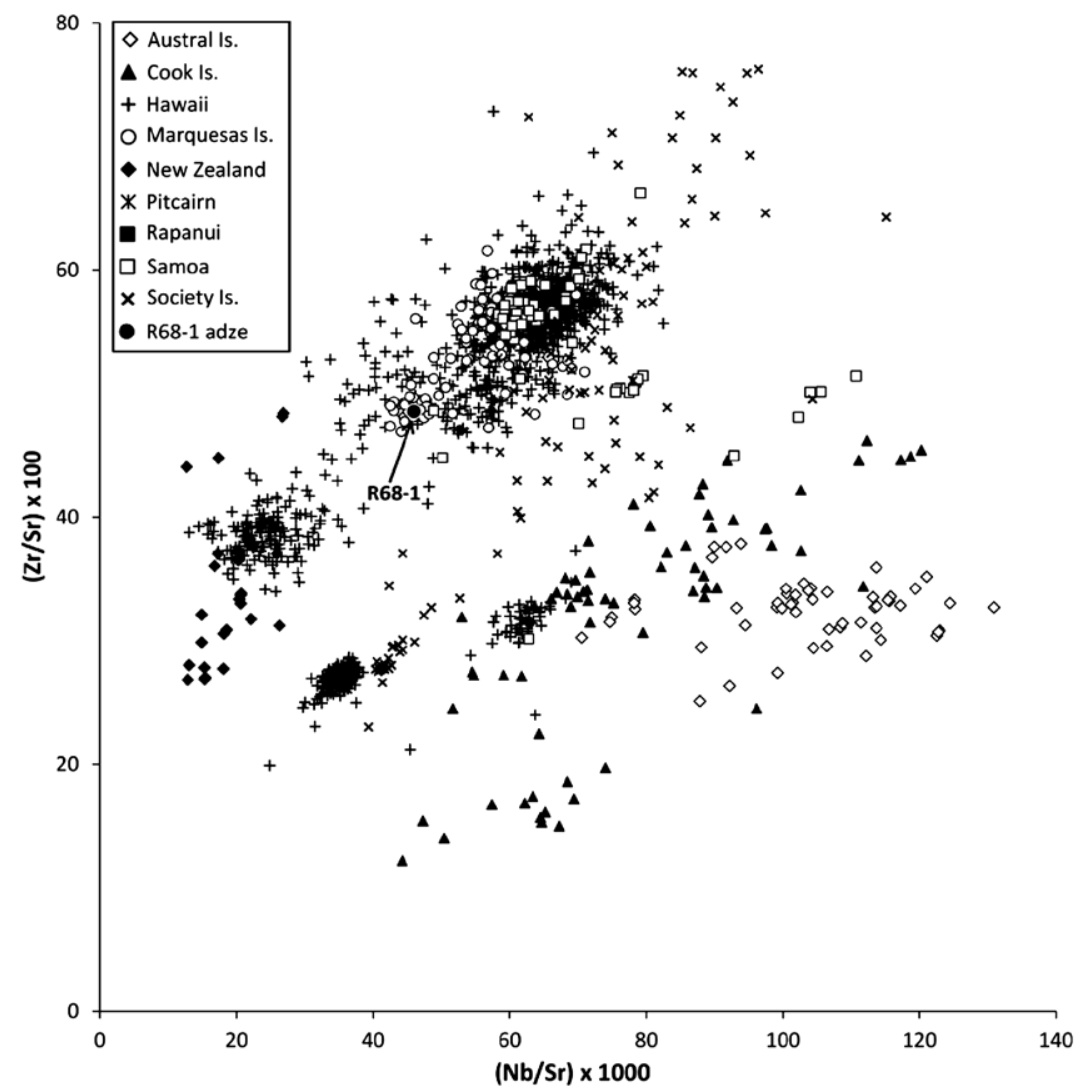

Figure 2. Bivariate scatterplot of trace element ratios for Polynesian basalt sources $(1000 \times \mathrm{Nb} / \mathrm{Sr}$ against $100 \times \mathrm{Zr} / \mathrm{Sr})$. Data are collated from all the works cited in the text that include values for the three trace elements.

which consists of dividing artefact values by source compositions, where a value of 1.00 represents an exact match to a source average and higher or lower values show increasing dissimilarity (see Table 1). Comparing the R68-1 adze to the source averages for Eiao and Killauea, and the single Malaeloa specimen, shows that Eiao is a much closer match for all elements except nickel. Moreover, the large differences between the adze and the Kīlauea and Malaeloa data for major elements silicon, sodium, aluminium, 
calcium and potassium suggest that the adze is unlikely to be derived from the same volcanic events that produced these deposits. Overall, our analysis indicates that the Eiao source provides the closest match for the Cook Island adze R68-1. While it is never possible to determine the origin of an artefact with absolute confidence, on the basis of our current knowledge, the adze is unlikely to have derived from any other known Polynesian basalt source.

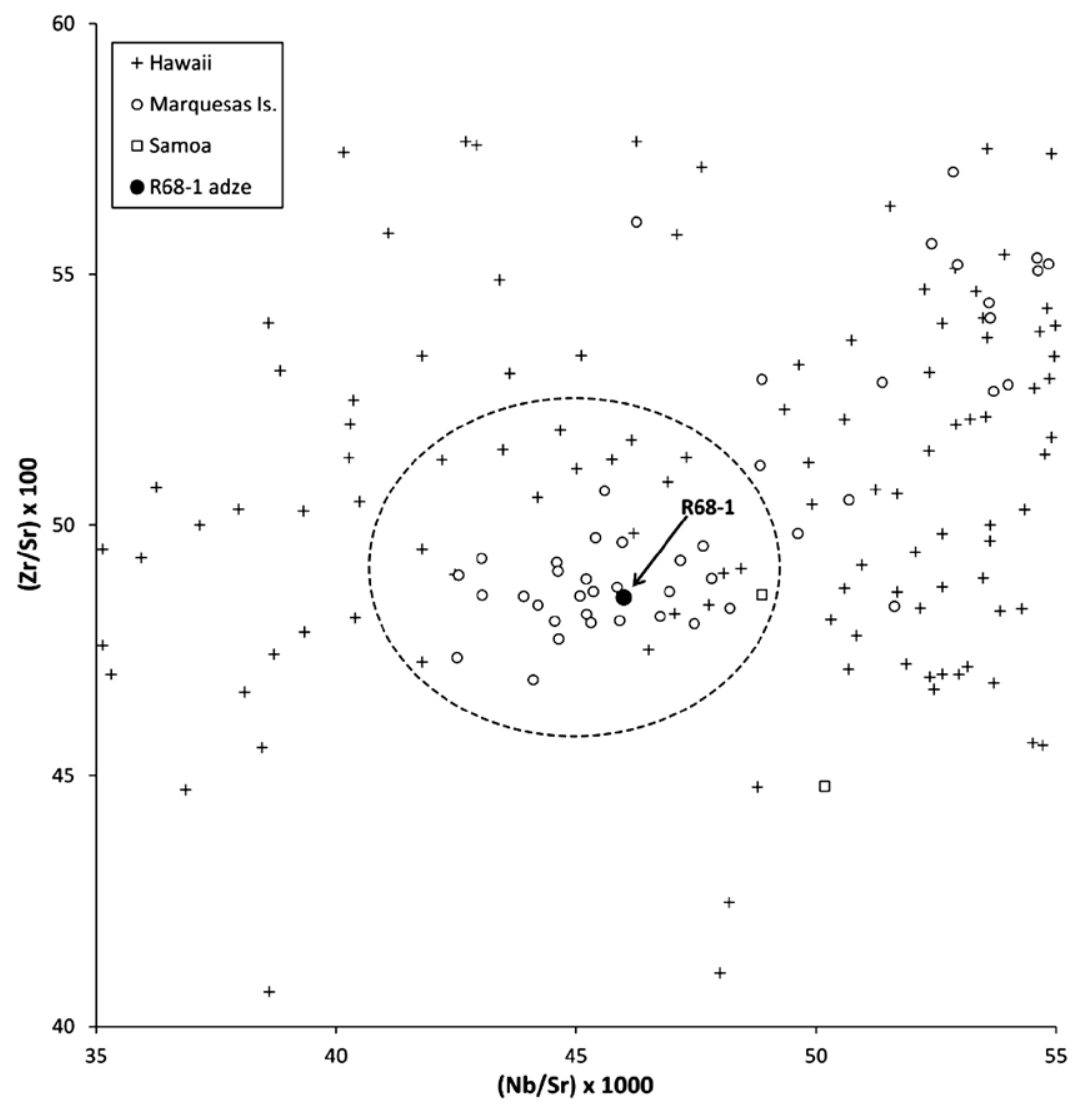

Figure 3. Bivariate scatterplot of Polynesian basalt source data clustering close to the R68-1 adze (1000 x Nb/Sr against $100 \times \mathrm{Zr} / \mathrm{Sr})$. 

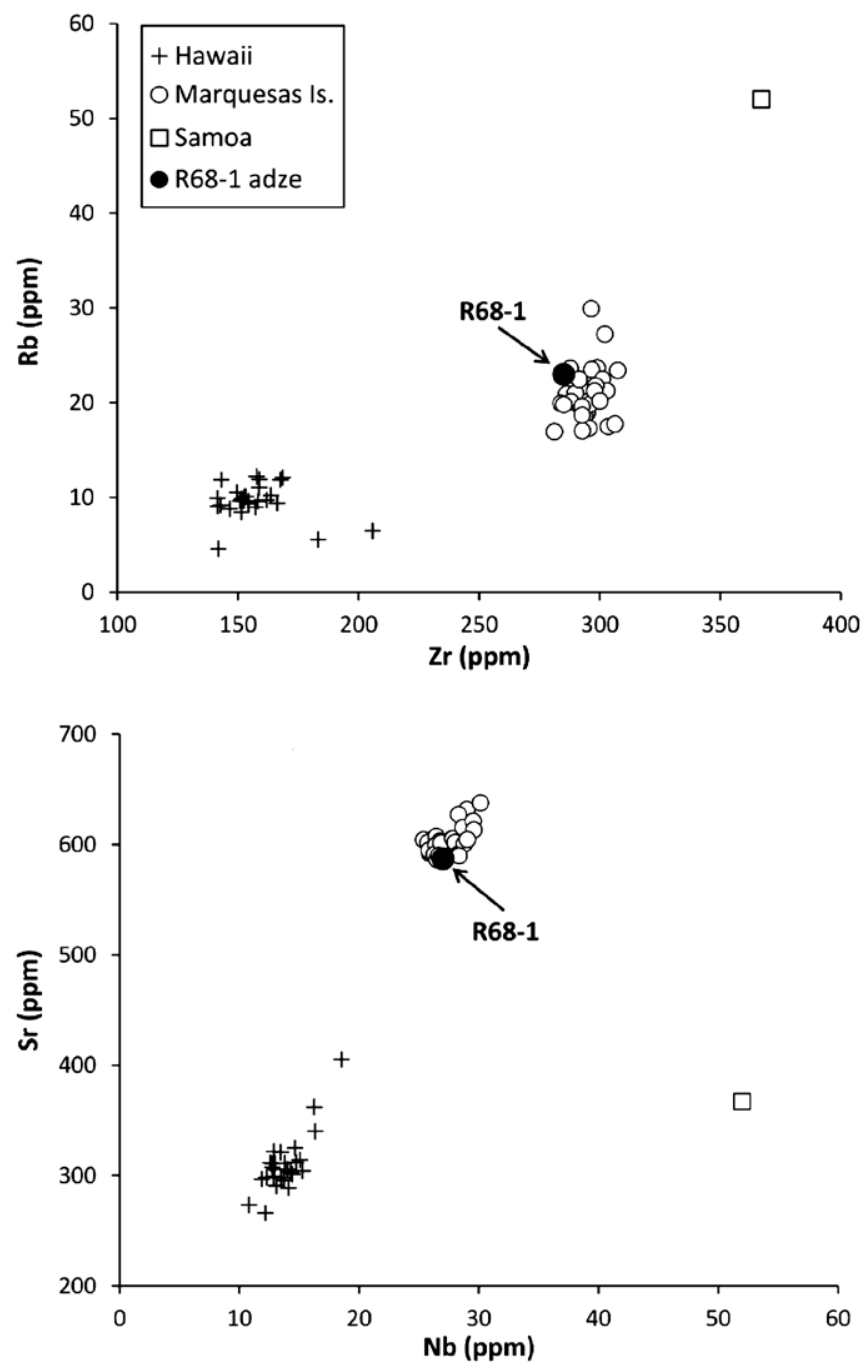

Figure 4. Bivariate scatterplots of $\mathrm{Zr}$ against $\mathrm{Rb}$ (top) and $\mathrm{Nb}$ against $\mathrm{Sr}$ (bottom) for source samples clustering near the R68-1 adze in Figure 3. Markers are jittered slightly $( \pm 0.25 \mathrm{ppm})$ to avoid overprinting. 


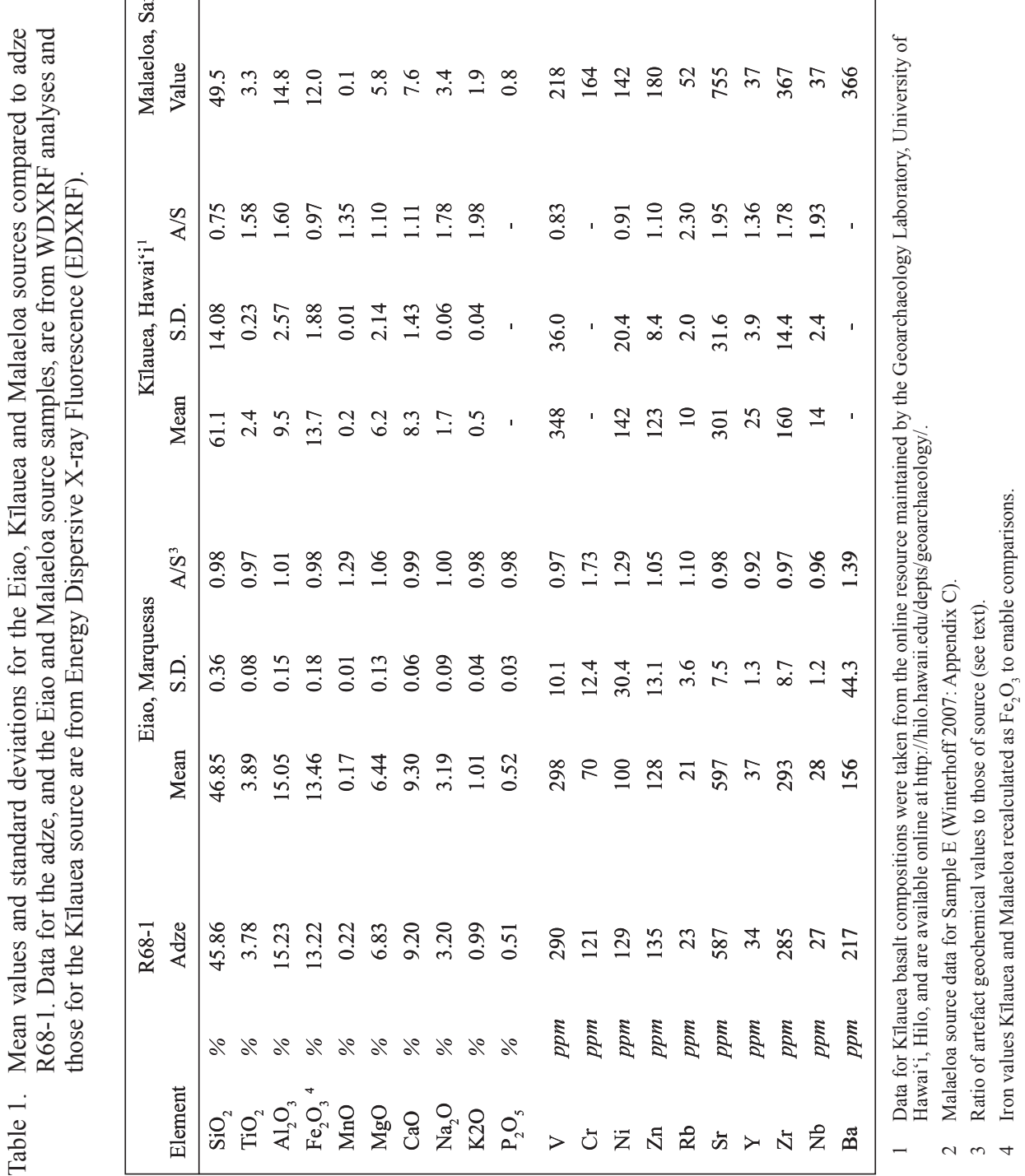

苛 


\section{DISCUSSION AND CONCLUSION}

As discussed above, previous studies have identified the importation of stone artefacts into the Cook Islands but, apart from small numbers of adzes from the Society Islands, extra-archipelago contacts seem to have been mainly with Samoa to the west (see Allen and Johnson 1997, Walter and Sheppard 1996, Weisler 1993). In addition to Samoan adzes, Walter and Dickinson (1989) have suggested a West Polynesian, possibly Tongan, source for two ceramic sherds recovered from a 14th century context on Ma'uke. Archaeological findings of connections with West Polynesia are reflected in Cook Island oral traditions, which speak of direct contact with Samoa (Gill 1880, Nicholas 1892, Stair 1895; see also Allen 1996, Bellwood 1978, Walter and Sheppard 1996).

Although there has been no direct archaeological evidence until now, contact between the Cook Islands and Marquesas also is a recurring theme in Polynesian traditions. There are several versions of a Marquesan legend concerning the voyage of Aka, who travelled from the Marquesas to the Cook Islands to obtain red parrot feathers as gifts for his children (Handy 1930: 130, Kaiser and Elbert 1989, Terrell 1988), while the Rarotongan traditions recorded by Te Ariki-Tara-Are during the 19th century recount several episodes in a protracted conflict between Tangiia and his cousin Tu-tapu, a chief from the Marquesas (Te Ariki-Tara-Are 1920; see also Walter and Moeka'a 2000). In another Rarotongan legend, two Marquesans, Tangaroa and Aumake, are reputed to have come to Rarotonga and constructed a road around the island (Browne 1897). There are also traditions of Cook Islanders visiting the Marquesas; one recounts the voyage of Rau Mataiapo and his son, from Puaikura in Rarotonga, who went to Nuku Hiva to deliver a shipment of red feathers as payment for "secret" tattoo designs that were obtained from a Marquesan chief, Tui, the year before - presumably during a previous voyage (Jonassen 1981: 27).

Our identification of an adze from Eiao provides the first physical evidence of the prehistoric links between the Cook Islands and the Marquesas that are indicated by oral traditions. This study also demonstrates the usefulness of re-examining results from previous studies in light of the more comprehensive reference data that has become available. More broadly, the Marquesas-Cook Islands relations evidenced here gives new insight into the potential scale of post-settlement interaction. Although more evidence is needed to place these contacts in a temporal context, and to make inferences regarding their frequency, the current find opens tantalising possibilities for future research. 


\section{ACKNOWLEDGEMENTS}

The authors would like to acknowledge George Cowan at the Cook Islands Library and Museum Society for providing access to the adzes that were originally sampled by Sheppard and Walter. John Sinton is thanked for providing McAlister with further information about the specimens used to calculate the Eiao source averages published in Sinton and Sinoto (1997). Helpful comments were provided by an anonymous reviewer.

\section{REFERENCES}

Allen, M.S., 1996. Patterns of interaction in southern Cook Island prehistory. Indo Pacific Prehistory: The Chiang Mai Papers. Bulletin of the Indo-Pacific Association 15, Volume 2. Canberra: Australian National University, pp. 13-21. Allen, M.S. and K.T.M. Johnson, 1997. Tracking ancient patterns of interaction: Recent geochemical studies in the southern Cook Islands. In M.I. Weisler (ed.), Prehistoric Long-Distance Interaction in Oceania: An Interdisciplinary Approach. New Zealand Archaeological Association Monograph 21. Auckland, pp. 111-33. Allen, M.S. and J.G. Kahn, 2010. Central East Polynesia: An introduction. Archaeology in Oceania 45: 49-53.

Allen, M.S. and A. McAlister, 2013. Early Marquesan settlement and patterns of interaction: New insights from Hatiheu Valley, Nuku Hiva Island. Journal of Pacific Archaeology 4 (1): 90-109.

Aswani, S. and P. Sheppard, 2003. The archaeology and ethnohistory of exchange in pre-colonial and colonial Roviana: Gift, commodities, and inalienable possessions. Current Anthropology 44: s51-78.

Baxter, M.J., 1994. Exploratory Multivariate Analysis in Archaeology. Edinburgh: Edinburgh University Press.

Bellwood, P.S., 1978. Archaeological Research in the Cook Islands. Pacific Anthropological Records 27. Honolulu: Bishop Museum Press.

Best, S.B., 1984. Lakeba: The Prehistory of a Fijian Island. Unpublished PhD thesis, University of Auckland.

Best, S.B., P.J. Sheppard, R.C. Green and R.J. Parker, 1992. Necromancing the stone: Archaeologists and adzes in Samoa. Journal of the Polynesian Society 101 (1): 45-85.

Bollt, R.J., 2008. Peva: The Archaeology of an Austral Island Settlement. Bishop Museum Bulletin in Anthropology 12. Honolulu: Bishop Museum Press.

Browne, A.H., 1897. An account of some early ancestors of Rarotonga. Journal of the Polynesian Society 6 (1): 1-10.

Cann, J.R. and C. Renfrew, 1964. The characterization of obsidian and its application to the Mediterranean Region. Proceedings of the Prehistoric Society 30: 111-31.

Charleux, M., A. McAlister, P.R. Mills and S.P. Lundblad, in press. Non-destructive XRF analyses of fine-grained basalts from Eiao, Marquesas Islands, Journal of Pacific Archaeology. 
Collerson, K.D. and M.I. Weisler, 2007. Stone adze compositions and the extent of ancient Polynesian voyaging and trade. Science 307: 1907-11.

Di Piazza, A. and E. Pearthree, 2001. Voyaging and basalt exchange in the Phoenix and Line archipelagoes: The viewpoint from three mystery islands. Archaeology in Oceania 36: 146-52.

Gill, W.W., 1880. Historical Sketches of Savage Life in Polynesia. Wellington: Government Printer.

Hancock, R.G.V., K.E. Hancock and J.K. Hancock, 2008. Thoughts on the utility of a bivariate-splitting approach to Olmec ceramic data interpretation. Archaeometry 50 (4): 710-26.

Handy, E.S.C., 1930. Marquesan Legends. Bishop Museum Bulletin 69. Honolulu: Bishop Museum Press.

Hermann, A., 2011. Dynamique de production des industries lithiques en Polynésie central: Travaux entrepris dans l'île de Tubuai, Archipel des Australes, Polynésie française, 2010-2011. Centre International de Recherche Archéologique sur la Polynésie (CIRAP) Laboratoire EAST (Sociétés traditionnelles du Pacifique), Université de la Polynésie Française.

Hosler, D. and A. Macfarlane, 1996. Copper sources, metal production, and metals trade in Late Postclassic Mesoamerica. Science 273: 1819-24.

Hughes, R.E. 1986. Diachronic Variability in Obsidian Procurement Patterns in Northeastern California and Southcentral Oregon. University of California Publications in Anthropology 17. Berkeley.

Irwin, G.J., 1990. Human colonisation and change in the remote Pacific. Current Anthropology 31 (1): 90-94.

1992. The Prehistoric Exploration and Colonisation of the Pacific. Cambridge: Cambridge University Press.

Johnson, P.R., 2005. Instrumental Neutron Activation Analysis (INAA) Characterization of Pre-Contact Basalt Quarries on the American Samoan Island of Tutuila. Unpublished MA thesis, Department of Anthropology,Texas A\&M University. 2010. Elemental analysis of fine-grained basalt sources from the Samoan island of Tutuila: Applications of energy dispersive X-ray fluorescence (EDXRF) and instrumental neutron activation analysis (INAA) towards an intra-island provenance study. In M.S. Shackley (ed.), X-Ray Fluorescence Spectrometry $(X R F)$ in Geoarchaeology. New York: Springer, pp. 143-60.

Jonassen, J., 1981. Cook Islands Legends. Suva: Institute of Pacific Studies, University of the South Pacific, in association with the Ministry of Education, Rarotonga, Cook Islands, and the South Pacific Creative Arts Society.

Kahn, J.G., P. Mills, S.P. Lundblad, J. Holson and P.V. Kirch, 2008. Tool production at

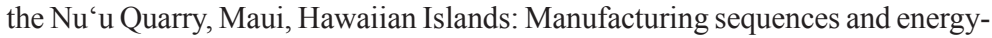
dispersive X-ray fluorescence analyses. New Zealand Journal of Archaeology 30: 135-65.

Kahn, J.G., J.M. Sinton, P.R. Mills, and S.P Lundblad, 2013. X-ray fluorescence analysis and intra-island exchange in the Society Island Archipelago (Central Eastern Polynesia). Journal of Archaeological Science 40: 1194-202. 
Kaiser, M. and S.H. Elbert, 1989. Ka'akai o te henua 'enana - history of the land of men. Journal of the Polynesian Society 98 (1): 77-84.

Kennett, D.J., A.J. Anderson, M.J. Cruz, G.R. Clark and G.R. Summerhayes, 2004. Geochemical characterization of Lapita pottery via Inductively Coupled Plasmamass Spectrometry (ICP-MS). Archaeometry 46 (1): 35-46.

Kirch P.V., 1988. Long-distance exchange and island colonisation: The Lapita case. Norwegian Archaeological Review, 21: 103-17.

Kirch P.V. and J.G. Kahn, 2007. Advances in Polynesian prehistory: A review and assessment of the past decade (1993-2004). Journal of Archaeological Research 15: 191-238.

Kirch, P.V., P.R. Mills, S.P. Lundblad, J. Sinton and J.G. Kahn, 2012. Interpolity exchange of basalt tools facilitated via elite control in Hawaiian archaic states. Proceedings of the National Academy of Sciences of the United States of America 109 (4): 1056-1061.

Knapp, A.B., 2000. Archaeology, science-based archaeology and the Mediterranean Bronze Age metals trade. European Journal of Archaeology 3 (1): 31-56.

Linton, R., 1925. Archaeology of the Marquesas Islands. Bernice Pauahi Bishop Museum Bulletin 23 / Bayard Dominick Expedition Publication No. 10. Honolulu: Bishop Museum Press.

McAlister, A., 2011. Methodological Issues in the Geochemical Characterisation and Morphological Analysis of Stone Tools: A Case Study from Nuku Hiva, Marquesas Islands, East Polynesia. Unpublished PhD thesis, University of Auckland.

McCoy, M.D., 2011. Geochemical characterization of volcanic glass from $\mathrm{Pu}$ 'u Wa'awa'a, Hawai'i Island. Rapa Nui Journal 25 (2): 41-49.

McCoy, M.D., P.R. Mills, S.P. Lundblad, T. Rieth, J.G. Kahn and R. Gard, 2011. A cost surface model of volcanic glass quarrying and exchange in Hawai'i. Journal of Archaeological Science 38: 2547-60.

Mills, P.R., S.P. Lundblad, J.S. Field, A.B. Carpenter, W.K. McElroy and P. Rossi, 2010. Geochemical sourcing of basalt artifacts from Kaua' $i$, Hawaiian Islands. Journal of Archaeological Science 37 (12): 3385-93.

Mills, P.R., S.P. Lundblad, K. Hon, J.J. Moniz-Nakamura, L.K. Kahahane, A. DrakeRaue, T.M. Souza and R. Wei, 2011. Reappraising craft specialization and exchange in pre-contact Hawai'i through non-destructive sourcing of basalt adze debitage. Journal of Pacific Archaeology 2 (2): 79-92.

Mills, P.R., S.P. Lundblad, J.G. Smith, P.C. McCoy and S.P. Nalemaile, 2008. Science and sensitivity: A geochemical characterization of the Mauna Kea adze quarry complex, Hawai'i Island, Hawaii. American Antiquity 74: 743-58.

Mintmier, M., P.R. Mills and S.P. Lundblad, 2012. Energy-dispersive X-ray fluorescence analysis of Haleakalā basalt adze quarry materials, Maui, Hawai'i. Journal of Archaeological Science, 39: 615-23.

Neff, H., 1995. A role for "sourcing" in evolutionary archaeology. In P.A. Teltser (ed.), Evolutionary Archaeology: Methodological Issues. Tucson: University of Arizona Press, pp. 69-112.

Nicholas, H., 1892. Genealogies and historical notes from Rarotonga. Journal of the Polynesian Society 1: 20-29, 65-75. 
Parker, R.J. and P.J. Sheppard, 1997. Pacific island adze geochemistry studies at the University of Auckland. In M.I. Weisler (ed.), Prehistoric Long-Distance Interaction in Oceania: An Interdisciplinary Approach. New Zealand Archaeological Association Monograph 21. Auckland, pp. 205-11.

Rolett, B.V., 1998. Hanamiai: Prehistoric Colonization and Cultural Change in the Marquesas Islands (East Polynesia). Yale University Publications in Anthropology 81. New Haven: Department of Anthropology and The Peabody Museum.

2001. Redécouvert de la carrière préhistorique d'Eiao aux îles Marquises. Bulletin de la Société des Études Océaniennes 289/290/291: 132-44.

Rolett, B.V., E. Conte, E. Pearthree and J.M. Sinton, 1997. Marquesan voyaging: Archaeometric evidence for inter-island contact. In M.I. Weisler (ed.), Prehistoric Long-Distance Interaction in Oceania: An Interdisciplinary Approach. New Zealand Archaeological Association Monograph 21. Auckland, pp. 134-48.

Saitowitz, S.J. and D.L. Read, 2001. Physical and chemical analysis of glass beads from Iron Age sites in northern Thailand: Preliminary findings. In M. Jones and P. Sheppard (eds), Australasian Connections and New Directions. Proceedings of the Seventh Archaeometry Conference. Auckland: University of Auckland, pp. 307-27.

Shackley, M.S. (ed.), 2010. X-Ray Fluorescence Spectrometry (XRF) in Geoarchaeology. New York: Springer.

Sheppard, P.J., G.J. Irwin, S.C. Lin and C.P. McCaffrey, 2011. Characterization of New Zealand obsidian using PXRF. Journal of Archaeological Science 38 (1): 45-56.

Sheppard, P.J., C. Sand and R.J. Parker, 2001. Sourcing Walpole Island: Problems and prospects in Pacific adze sourcing. In M. Jones and P. Sheppard (eds), Australasian Connections and New Directions. Proceedings of the Seventh Archaeometry Conference. Auckland: University of Auckland, pp. 349-63.

Sheppard, P.J., R.K. Walter and R.J. Parker, 1997. Basalt sourcing and the development of Cook Island exchange systems. In M.I. Weisler (ed.), Prehistoric LongDistance Interaction in Oceania: An Interdisciplinary Approach. New Zealand Archaeological Association Monograph 21. Auckland, pp. 85-110.

Sinton, J.M. and Y.H. Sinoto, 1997. A geochemical database for Polynesian adze studies. In M.I. Weisler (ed.), Prehistoric Long-Distance Interaction in Oceania: An Interdisciplinary Approach. New Zealand Archaeological Association Monograph 21. Auckland, pp. 194-204.

Stair, J.B., 1895. Floatsam and jetsam from the great ocean: Or, summary of early Samoan voyages and settlement. Journal of the Polynesian Society 4 (2): 99-131.

Suggs, R.C., 1961. The Archaeology of Nuku Hiva, Marquesas Islands, French Polynesia. Anthropological Papers of the American Museum of Natural History 49, Part 1. New York.

Te Ariki-Tara-Are, 1920. History and traditions of Rarotonga: Part X and XI. Journal of the Polynesian Society 29 (114): 45-69.

Terrell, J. (ed.), 1988. Von Den Steinen's Marquesan Myths. Canberra: Target Oceania/ The Journal of Pacific History.

Walter, R.K., 1990. The Southern Cook Islands in Eastern Polynesian Prehistory. Unpublished $\mathrm{PhD}$ thesis, University of Auckland. 
1998. Anai 'o: The Archaeology of a Fourteenth Century Polynesian Community in the Cook Islands. New Zealand Archaeological Association Monograph 22. Dunedin.

Walter, R.K. and W.R. Dickinson, 1989. A ceramic sherd from Ma'uke in the southern Cook Islands. Journal of the Polynesian Society 98 (4): 465-70.

Walter, R.K. and R. Moeka'a (eds), 2000. The Rarotongan Traditions of Te Ariki Tara Are. Memoir No. 51. Auckland: The Polynesian Society.

Walter, R.K. and P.J. Sheppard, 1996. The Ngati Tiare adze cache: Further evidence of prehistoric contact between west Polynesia and the southern Cook Islands. Archaeology in Oceania 31: 33-39.

2001. Cook Island basalt sourcing: Current issues and directions. In M. Jones and P.J. Sheppard (eds), Australasian Connections and New Directions: Proceedings of the 7th Australasian Archaeometry Conference. Auckland: University of Auckland, pp. 383-99.

Ward, G.K., 1972. Obsidian and New Zealand Archaeology: A Paradigm for Sourcing Artefact Obsidians Using X-Ray Fluorescence Spectrography. Unpublished MA thesis, Department of Anthropology, University of Otago.

Weisler, M.I., 1993. Long-Distance Interaction in Prehistoric Polynesia: Three Case Studies. Unpublished PhD dissertation, University of California.

-1997a. Prehistoric long-distance interaction at the margins of Oceania. In M.I. Weisler (ed.), Prehistoric Long-Distance Interaction in Oceania: An Interdisciplinary Approach. New Zealand Archaeological Association Monograph 21. Auckland, pp. 149-72.

1997b. Introduction. In M.I. Weisler (ed.), Prehistoric Long-Distance Interaction in Oceania: An Interdisciplinary Approach. New Zealand Archaeological Association Monograph 21. Auckland, pp. 7-18.

- 1998. Hard evidence for prehistoric interaction in Polynesia. Current Anthropology 39 (4): 521-32.

2008. Tracking ancient routes across Polynesian seascapes with basalt artifact geochemistry. In B. David and J. Thomas (eds), Handbook of Landscape Archaeology. Walnut Creek: Left Coast Press, pp. 536-43.

Weisler M.I., S.L. Collins, Y. Feng, J. Zhao, C. Shipton and X. Wei, 2013. A new major adze quarry from Nānākuli, $\mathrm{O}^{`}$ ahu: Implications for interaction studies in Hawai'i. Journal of Pacific Archaeology 4 (2): 35-57.

Weisler, M.I., E. Conte and P.V. Kirch, 2004. Material culture and geochemical sourcing of basalt artifacts. In E. Conte and P.V. Kirch (eds), Archaeological Investigations in the Mangareva Islands (Gambier Archipelago), French Polynesia. Contribution Number 62. Berkeley: Archaeology Research Facility, University of California, pp. 128-48.

Weisler, M.I., P. Kirch and J. Endicott, 1994. The Mata'are basalt source: Implications for prehistoric interaction studies in the Cook Islands. Journal of the Polynesian Society 103 (2): 203-16. 
Weisler, M.I. and J.M. Sinton, 1997. Towards identifying prehistoric interaction systems in Polynesia. In M.I. Weisler (ed.), Prehistoric Long-Distance Interaction in Oceania: An Interdisciplinary Approach. New Zealand Archaeological Association Monograph 21. Auckland, pp. 173-93.

Winterhoff, E., 2007. The Political Economy of Ancient Samoan Basalt Adze Production and Linkages to Social Status. Unpublished PhD dissertation, University of Oregon.

\begin{abstract}
We report on the provenance of an adze from the Cook Islands that was previously geochemically analysed by Sheppard, Walter and Parker (1997) but could not be assigned a source at that time because of the paucity of reference data. Drawing on basalt characterisation studies from the last two decades, we can now demonstrate that the adze most likely derives from the Marquesan island of Eiao, over $2500 \mathrm{~km}$ to the east. This find extends the western distribution of the Eiao basalt source, which was previously limited to the Society Islands.
\end{abstract}

Keywords: archaeology, Cook Islands, interaction, stone tools, X-ray fluorescence 
